\title{
Divine Presence and Absence in Exilic and Post-Exilic Judaism
}

\author{
Studies of the Sofja Kovalevskaja Research Group on Early Jewish Monotheism Vol. \\ II
} Ed. by Nathan MacDonald and Izaak J. de Hulster

[Göttliche Präsenz und Abwesenheit im exilischen und nach-exilischen Judentum.]

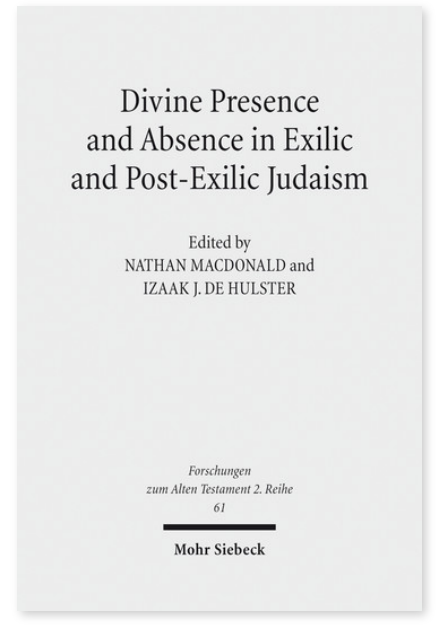

2013. XVI, 323 Seiten. FAT II 61

ISBN 978-3-16-152434-9

DOI 10.1628/978-3-16-152434-9

eBook PDF 104,00€

ISBN 978-3-16-152433-2

fadengeheftete Broschur 104,00€
Veröffentlicht auf Englisch.

Die katastrophalen Ereignisse zu Beginn des sechsten Jahrhunderts v. Chr. führten zu einer theologischen Krise innerhalb der Elite Judas. Das verhängnisvolle Ende des einzigen verbleibenden hebräischen Königreichs wurde durch eine Theologie erklärt, die davon sprach, dass Gott sein Volk verlassen hat, einem Motiv, welches im Nahen Osten der Antike weithin verständlich war. Viele Jahre später würden jüdische Vertriebene zurückkehren, um Jerusalem wieder aufzubauen und sich dort niederzulassen. Während ihrer Zeit in Babylonien und während der persischen Ära definierte diese Gruppe das traditionelle Verständnis der göttlichen Präsenz neu und entwickelte diverse neue Ansätze, die sowohl YHWH's Treue zu Jerusalem erklärte als auch die kataklystischen Ereignisse, die ihnen widerfahren waren. Die Autoren dieser Aufsatzsammlung untersuchen, wie sich die Vorstellung von göttlicher Präsenz und Abwesenheit verändert hat und welche konzeptionellen Muster für deren Beschreibung verwendet wurden. Dieser Band ist die erste Veröffentlichung der Sofja-Kovalevskaja Forschungsgruppe unter der Führung von Nathan MacDonald. Mit Beiträgen von: Claus Ambos, Bob Becking, Angelika Berlejung, Joel Burnett, Stephen Cook, Michael Emmendörffer, Lisbeth S. Fried, Trevor Hart, Nathan MacDonald, Jill Middlemas, William Tooman, Johannes Zachhuber

\section{Inhaltsübersicht}

Table of Contents: Nathan MacDonald: Introduction - Trevor Hart: Complicating Presence: Interdisciplinary Perspectives on a Theological Question - Johannes Zachhuber: Transzendenz und Immanenz als Interpretationskategorien antiken Denkens im 19. und 20. Jahrhundert - Claus Ambos: Tempel, Kultbild, Priester - Überlegungen zu den Voraussetzungen für göttliche Präsenz im Alten Orient und zu den Gefahren ihrer Beeinträchtigung - Angelika Berlejung: Divine Presence for Everybody: Presence Theology in Everyday Life - Nathan MacDonald: The Spirit of YHWH: An Overlooked Conceptualization of Divine Presence in the Persian Period - Stephen Cook: God's Real Absence and Real Presence in Deuteronomy and Deuteronomism - William Tooman: Waiting for God: Conditions for the Restoration of the Divine Presence in Ezekiel - Jill Middlemas: Multiple Imaging as Literary Aniconism in the Prophets - Joel Burnett: The Anticipated Rebuilding of the Jerusalem Temple as Reflected in the Elohistic Psalter and its Background in Mesopotamian Hymn Tradition - Michael Emmendörffer: Das Gebet in der Krise oder die Abwesenheit Jahwes als Thema der Psalmen - Bob Becking: Silent Witness: The Symbolic Presence of God in the Temple Vessels in Ezra-Nehemiah - Lisbeth S. Fried: The Torah of God as God: The Exaltation of the Written Law Code in EzraNehemiah

Izaak J. de Hulster Born 1979; 2008 PhD (Utrecht); since 2014 University Researcher at the Faculty of Theology, University of Helsinki; 2017 Habilitation (Göttingen).

https://orcid.org/0000-0003-0706-4480

Nathan MacDonald Born 1975; studied theology and classical Hebrew in Cambridge and Durham; currently University Lecturer in Hebrew Bible at the University of Cambridge and Fellow of St John's College.

Jetzt bestellen:

https://mohrsiebeck.com/buch/divine-presence-and-absence-in-exilic-and-post-exilic-judaism-9783161524349?no cache=1 order@mohrsiebeck.com

Telefon: +49 (0)7071-923-17

Telefax: $+49(0) 7071-51104$ 